\title{
The Role of High Concentrations of Homocysteine for the Development of Fetal Growth Restriction
}

\section{O papel de altas concentrações de homocisteína para o desenvolvimento da restrição de crescimento fetal}

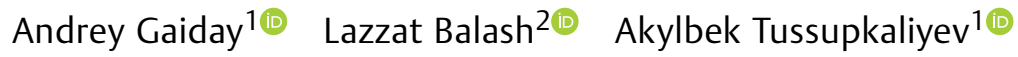 \\ ${ }^{1}$ West Kazakhstan Marat Ospanov Medical University, Aktobe, \\ Address for correspondence Andrey Gaiday, Department of \\ Kazakhstan \\ 2 L.N.Gumilyov Eurasian National University, Nur-Sultan, Kazakhstan \\ Obstetrics and Gynecology, West Kazakhstan Marat Ospanov Medical \\ University, Maresyev str, 68, Aktobe, Republic of Kazakhstan \\ (e-mail: a.gaiday@mail.ru).
}

Rev Bras Ginecol Obstet 2022;44(4):352-359.

\begin{abstract}
Objective To assess homocysteine (Hcy) levels in the three trimesters of pregnancy in women with fetal growth restriction (FGR) and to evaluate the role of Hcy as a possible predictor of FGR.

Methods A total of 315 singleton pregnant women were included in the present prospective cohort study and were monitored since the $1^{\text {st }}$ trimester of pregnancy before delivery. Newborns were monitored for the first 7 days of life. Patients who had risk factors for FGR were excluded. Fetal growth restriction was defined according to uterine fundal height ( $<10$ percentile), ultrasound fetometry ( $<5$ percentile), and anthropometry of newborns ( $<5$ percentile). The concentrations of Hcy were detected at between 10 and 14, between 20 and 24, and between 30 and 34 weeks of pregnancy by enzyme-linked immunosorbent assay (ELISA). Receiver operating characteristics (ROC) curve test and diagnostic odds ratio (DOR) were performed to evaluate the results of ELISA.

\section{Keywords}

- fetal growth restriction

- homocysteine

- hyperhomocysteinemia

- prediction of fetal growth restriction

Results The concentration of Hcy in patients with FGR was $19.65 \mathrm{umol} / \mathrm{L}$ at between 10 and 14 weeks, compared with 9.28 umol/L in patients with normal fetal growth $(p<0.0001)$. The optimal cut-off level for Hcy in the $1^{\text {st }}$ trimester of pregnancy was $>13.9$ umol/L with AUC 0.788 , sensitivity of $75 \%$, specificity of $83.6 \%$, and DOR of 15.2 .

Conclusion Assessment of serum Hcy concentration may be used as a predictor of FGR, with the highest diagnostic utility in the $1^{\text {st }}$ trimester of pregnancy.
\end{abstract}

received

March 24, 2021

accepted

December 17, 2021

published online

February 17, 2022
DOI https://doi.org/ $10.1055 / \mathrm{s}-0042-1743093$ ISSN $0100-7203$.
(C) 2022. Federação Brasileira de Ginecologia e Obstetrícia. All rights reserved.

This is an open access article published by Thieme under the terms of the Creative Commons Attribution License, permitting unrestricted use, distribution, and reproduction so long as the original work is properly cited. (https://creativecommons.org/licenses/by/4.0/)

Thieme Revinter Publicações Ltda., Rua do Matoso 170, Rio de Janeiro, RJ, CEP 20270-135, Brazil 


\section{Resumo}

\section{Palavras-chave}

- restrição de crescimento fetal

- homocisteína

- hiperhomocisteinemia

- predição de restrição de crescimento fetal
Objetivo Avaliar os níveis de homocisteína (Hcy) em três trimestres da gravidez em mulheres com restrição de crescimento fetal (FGR, na sigla em inglês) e avaliar o papel da Hcy como possível preditor de FGR.

Métodos Um total de 315 gestantes solteiras foram incluídas no presente estudo de coorte prospectivo e monitoradas desde o $1^{\circ}$ trimestre de gravidez antes do parto. Os recém-nascidos foram acompanhados durante os primeiros 7 dias de vida. Pacientes que apresentam fatores de risco para FGR foram excluídos. A FGR foi definida de acordo com a altura do fundo do útero (< percentil 10), ultrassonografia fetometria $(<$ percentil 5) e antropometria dos recém-nascidos (< percentil 5). As concentrações de Hcy foram detectadas entre 10 e 14, entre 20 e 24 e entre 30 e 34 semanas de gravidez por ensaio de imunoabsorção enzimática (ELISA, na sigla em inglês). O teste da curva das características de operação do receptor (ROC, na sigla em inglês) e a razão de chances de diagnóstico (DOR, na sigla em inglês) foram realizados para avaliar os resultados do ELISA.

Resultados A concentração de Hcy em pacientes com FGR foi de 19,65 umol/L entre 10 e 14 semanas, em comparação com 9,28 umol/L em pacientes com crescimento fetal normal $(p<0,0001)$. O nível de corte ideal para Hcy no $1^{\circ}$ trimestre da gravidez foi $>13,9 \mathrm{umol} / \mathrm{L}$ com AUC 0,788, sensibilidade de $75 \%$, especificidade de $83,6 \%$, e DOR 15,2.

Conclusão A avaliação da concentração sérica de Hcy pode ser usada como um preditor de FGR, com maior utilidade diagnóstica no $1^{\circ}$ trimestre de gravidez.

\section{Introduction}

Fetal growth restriction (FGR) occurs when the fetus does not reach its intrauterine potential for growth and development as a result of compromise in placental function. ${ }^{1}$ According to various sources, the incidence of FGR is between 5 and 10\% worldwide, and is the second cause of perinatal mortality. ${ }^{1}$ The risk of death of newborns with FGR increases between 2 and 4 times, and the negative outcomes of childbirth are manifested in newborns as hypothermia, hypoglycemia, hyperglycemia, persistent pulmonary hypertension, pulmonary hemorrhage, polycythemia, stillbirth, and intranatal asphyxia. $^{2}$

In the process of growth, the fetus produces hemodynamic and metabolic changes, in which an adequate trophoblast invasion is an important component, ${ }^{3}$ and endothelial and subendothelial changes can contribute to their violation. ${ }^{4}$ Today, it is known that the underlying causes of FGR are genetic, placental, fetal, and maternal factors. $2,5,6$

An important physiological process that ensures normal perfusion of the placenta is the invasion of trophoblast villi and the reshuffle of the cytotrophoblast from the epithelial to the endothelial phenotype, which is called pseudovasculogenesis. ${ }^{7}$ Subsequently, the remodeling of the spiral arteries occurs, while the cytotrophoblast increases the expression of vascular endothelial growth factor (VEGF) and placental growth factor (PLGF). ${ }^{8}$ Nowadays, serum biomarkers are increasingly preferred for the prediction and diagnosis of FGR, of which the most commonly used are pregnancyassociated plasma protein-A (PAPP-A), $\alpha$-fetoprotein (AFP), placental growth factor (PLGF), and soluble fms-like tyrosine kinase-1 (sFlt-1). ${ }^{6,9-13}$ Along with well-known biomarkers, in the last decade, studies indicated the possibility of using serum homocysteine (Hcy) for the prediction and diagnosis of preeclampsia (PE) and FGR; ${ }^{14-18}$ however, there are no studies available from the Kazakhstan population. The development of FGR in hyperhomocysteinemia (HHcy) may be due to the elevation of asymmetric dimethylarginine (ADMA) levels since Hcy has an inhibitory effect on ADMA metabolism. Injury to endothelial cells is also associated with HHcy, which leads to changes in the coagulation system, platelet activation, and thrombogenesis. ${ }^{19}$

In this study, we hypostatized that HHcy could be considered as an additional marker for the prediction and diagnosis of FGR. The aim of our study was to assess Hcy levels in the 3 trimesters (10-14, 20-24, and 30-34 weeks) of pregnancy in women with FGR and to evaluate the role of Hcy as a possible predictor of FGR. Confirmation of the hypothesis can be used to identify groups of patients with HHcy, as well as to search for the prevention of FGR from the $1^{\text {st }}$ trimester of pregnancy.

\section{Methods}

The present study was part of the scientific program "Development and scientific substantiation of new technologies for protecting the health of newborns" and was approved by the Local Ethical Committee (protocol no. 12 28/12/2015) and registered at the National Center of Science and Technology Evaluation of the Republic of Kazakhstan (0107RKI00477). All patients signed a written informed consent to participate in the study. 
All patients were invited to participate in this prospective cohort study at the Aktobe city outpatient department during antenatal and postpartum periods and in the regional perinatal center (Aktobe, Kazakhstan) during the intrapartum and postpartum periods between April 2016 and February 2018. Of the 615 subjects, consent to participate in the study was obtained from 360 patients who were included in the study. A total of 45 patients did not complete the study: 7 (1.9\%) had miscarriages; 6 (1.7\%) changed their place of residence and were not available for observation; $8(2.2 \%)$ refused to continue the study; and, subsequently, 24 (6.7\%) had hypertensive disorders or diabetes mellitus and were excluded according to the study protocol. Finally, we studied 315 pregnancies from the $1^{\text {st }}$ trimester (between 10and 14 weeks) before birth. Newborns were monitored for the first 7 days of life. The inclusion criteria were age between 18 and 40 years old, singleton pregnancy, normal fetal anatomy, body mass index (BMI) between 19 and $30 \mathrm{~kg} / \mathrm{m}^{2}$, without preeclampsia. We excluded patients, who had confounders for FGR such as multiple pregnancies, fetuses with chromosomal anomalies, FGR in a previous pregnancy, diabetes, hematologic and autoimmune diseases, congenital disorders, lung diseases, kidney failure, history of chronic hypertension or preeclampsia, smoking, alcohol or drug abuse, and low socioeconomic status. ${ }^{1,2,5,20,21}$

The gestational age was determined by the date of the last menstruation by the Naegele rule, and by using a Samsung Medison RS80-A ultrasound machine (Samsung Medison, South Korea), transvaginal and transabdominal ultrasound fetometry were used, which determined the crown-rump length (CRL) and were compared with known values. ${ }^{22,23}$ In case of difference between the gestational age (according to the date of the last menstruation) and ultrasound fetometry $>5$ days, the gestational age was determined according to ultrasound data. ${ }^{24,25}$ Serial examination of the measurements of uterine fundal height and transabdominal ultrasound fetometry (abdominal circumference, head circumference, and femur length) every 4 weeks from 20 weeks of gestation were performed. Fetal growth restriction was determined as a primary $<10$ percentile or fetal growth arrest at initial normal rates of uterine fundal height in gravidogram ${ }^{26}$ and/or $<5$ percentile by the standard curve by ultrasound fetometry, ${ }^{27}$ which were necessarily confirmed by $<5$ percentile by the standard curve of the body weight, height, and BMI of the newborns regarding gestational age. ${ }^{28}$ The diagnosis of FGR was rejected if the anthropometric parameters of newborns were $>5$ percentile by the standard curve and the data were not evaluated in the study. The conditions of newborns were assessed using the Apgar scale and a complete clinical examination was performed.

Homocysteine concentrations were determined at between 10 and 14, between 20 and 24, and between 30 and 34 weeks of pregnancy by enzyme-linked immunosorbent assay (ELISA). Venous blood samples $(5 \mathrm{ml})$ were collected after overnight fasting and cancellation of folic acid supplements, drugs, or dietary supplements containing S-adenosyl-L-methionine intake for 14 days, into an AVATUBE vacuum container with an activator gel (Eco Pharm Interna- tional, Kazakhstan), then the samples were centrifuged at $1,500 \mathrm{rpm}$ no later than 30 minutes after the sample collection to split the pallets. The samples were stored at $-20^{\circ} \mathrm{C}$ for up to 8 weeks. Monoclonal antibodies Homocysteine EIA microtiter plate with ELISA reagents were used to detect Hcy (Axis-Shield Diagnostics Ltd, United Kingdom). The optical density was measured by photometry at $450 \mathrm{~nm}$ using a Dialab ELX808IU microplate reader (Dialab, Austria). Concentrations of the Hcy amino acid were obtained from the optical density data by applying a method of the standard curve. $^{29}$

Statistical analyses were performed by using Statistica 12.0 software (Stat Soft Inc., USA). The type of distribution was evaluated by the Shapiro-Wilk test. For data with an abnormal distribution, median (Me) with 25 to 75 interquartile range (IQR) were determined. Analyses for independent two variables were performed with the Mann-Whitney U-test and the Fisher exact test (two-tailed), whereas for the dependent variables the Friedman and Tukey post-hoc tests were applied. To determine the optimal cut-off levels for the concentration of Hcy, a receiver operating characteristics (ROC) curve test was applied, performed by the statistical processing program Med Calc 19.1 (Med Calc Software Ltd). Receiver operating characteristics analyses included evaluation of the area under the curve (AUC), sensitivity (Se), specificity ( $\mathrm{Sp}$ ), Youden index (J), negative likelihood ratio (-LR), and positive likelihood ratio (+LR). The diagnostic odds ratio (DOR) was calculated and evaluated for study groups according to a previously published protocol. ${ }^{30}$ Receiver operating characteristics curves have been compared by the DeLong et al. test. ${ }^{31}$

The level of statistical significance was defined as $p<0.05$.

The present study was approved by the Local Ethical Committee protocol no. 12 of December 28, 2105, at the West Kazakhstan Marat Ospanov Medical University. The present study was conducted in accordance with the Helsinki Declaration.

\section{Results}

After the clinical manifestation of FGR, the patients were divided into 2 groups: the FGR group, with 12 (3.8\%) cases, and the control group, with 305 (96.2\%) cases. There were no differences between the study groups in anamnestic, clinical, and ethnic data (-Table $\mathbf{1}$ ).

The newborns had a lower median of weight, height, BMI, and Apgar score, and were more often transferred to the intensive care unit in the FGR group $(\boldsymbol{p}<0.05)$ ( - Table 2 ). There were no differences in stillbirth, neonatal death, and malformations between FGR and the control group $(p>0.05)$ (-Table 2).

The medians of Hcy concentration in the patients with FGR were 19.65 umol/L at between 10-14 weeks, 18.49 umol/L at between 20 and 24 weeks, and $15.36 \mathrm{umol} / \mathrm{L}$ at between 30 and 34 weeks, which is significantly higher when compared with the control group $(p<0.05)$ ( - Table 3 ). In addition, we found that Hcy concentration was similar during the entire gestation within the FGR group, indicating 
Table 1 Clinical characteristics of the patients in the FGR and Control groups

\begin{tabular}{llll}
\hline & $\begin{array}{l}\text { FGR group } \\
(\boldsymbol{n}=12)\end{array}$ & $\begin{array}{l}\text { Control group } \\
(\boldsymbol{n}=305)\end{array}$ \\
\hline Age, years old, median (IQR) & $27(25-32)$ & $28(25-31)$ & $0.883^{\mathrm{a}}$ \\
Menarche, years old, median (IQR) & $14(13-14)$ & $13(13-14)$ & $0.587^{\mathrm{a}}$ \\
Abnormal menstrual function, $n$ & - & $6(1.9 \%)$ & - \\
Nulliparous, $n$ & $3(25 \%)$ & $65(21.3 \%)$ & $240(78.7 \%)$ \\
Multiparous, $n$ & $9(75 \%)$ & $70(22.9 \%)$ & $0.999^{\mathrm{b}}$ \\
Previous abortions, $n$ & $4(33.3 \%)$ & $71(23.3 \%)$ \\
Previous miscarriages, $n$ & $3(25 \%)$ & $16(5.2 \%)$ & $0.999^{\mathrm{b}}$ \\
Preterm labor, $n$ & $2(16.6 \%)$ & $22.4(20.6-24.6)$ \\
BMI, kg/m ${ }^{2}$, median (IQR) & $21.4(19.7-22.9)$ & $12(11-13)$ & $0.484^{\mathrm{b}}$ \\
Gestational age at admission, weeks, median (IQR) & $12.5(10-13.5)$ & $39(38-40)$ & $0.143^{\mathrm{b}}$ \\
Gestational age at delivery, weeks, median (IQR) & $39(37.5-40)$ & $0.832^{\mathrm{a}}$ \\
\hline
\end{tabular}

Abbreviations: BMI, body mass index; FGR, fetal growth restriction; IQR, interquartile range.

a Mann-Whitney U-test

btwo-tailed Fisher test

Table 2 Clinical characteristics newborns in the FGR and Control groups

\begin{tabular}{|c|c|c|c|}
\hline & $\begin{array}{l}\text { FGR group } \\
(n=12)\end{array}$ & $\begin{array}{l}\text { Control group } \\
(n=305)\end{array}$ & p-value \\
\hline Weight, grams, median (IQR) & $2200(2160-2430)$ & $3420(3130-3730)$ & $<0.0001^{a}$ \\
\hline Height, centimeters, median (IQR) & $47.5(46.5-50)$ & $53(52-55)$ & $<0.0001^{\mathrm{a}}$ \\
\hline BMI, $\mathrm{kg} / \mathrm{m}^{2}$, median (IQR) & $9.57(8.8-10.77)$ & $12(11.46-12.57)$ & $<0.0001^{\mathrm{a}}$ \\
\hline Apgar score, $1^{\text {st }}$ minute, median (IQR) & $7.5(5.5-9)$ & $9(8-9)$ & $<0.0001^{\mathrm{a}}$ \\
\hline Apgar score, $5^{\text {th }}$ minute, median (IQR) & $8.5(7.5-10)$ & $10(9-10)$ & $0.002^{\mathrm{a}}$ \\
\hline Hospitalization in the intensive care unit, $n$ & $4(33.3 \%)$ & $14(4.6 \%)$ & $0.002^{b}$ \\
\hline Stillbirth, $n$ & $1(8.3 \%)$ & $1(0.3 \%)$ & $0.074^{b}$ \\
\hline Neonatal death, $n$ & $1(8.3 \%)$ & $1(0.3 \%)$ & $0.074^{b}$ \\
\hline Malformations, $n$ & $1(8.3 \%)$ & $2(0.6 \%)$ & $0.109^{b}$ \\
\hline
\end{tabular}

Abbreviations: BMI, body mass index; FGR, fetal growth restriction; IQR, interquartile range.

aU-test Mann-Whitney

btwo-tailed Fisher test

Table 3 Analyses of the serum homocysteine concentrations during pregnancy in the FGR and Control groups

\begin{tabular}{|c|c|c|c|c|}
\hline & $\begin{array}{l}\text { Hcy concentration } \\
\text { in } 10-14 \text { weeks } \\
\text { Median (IQR) } \\
\text { (umol/L) }\end{array}$ & $\begin{array}{l}\text { Hcy concentration } \\
\text { in } 20-24 \text { weeks } \\
\text { Median (IQR) } \\
\text { (umol/L) }\end{array}$ & $\begin{array}{l}\text { Hcy concentration } \\
\text { in } 30-34 \text { weeks } \\
\text { Median (IQR) } \\
\text { (umol/L) }\end{array}$ & p-value \\
\hline $\begin{array}{l}\text { FGR group } \\
(n=12)\end{array}$ & $\begin{array}{l}19.65 \\
(10.88-22.28)\end{array}$ & $\begin{array}{l}18.49 \\
(6.39-25.8)\end{array}$ & $\begin{array}{l}15.36 \\
(7.83-24.87)\end{array}$ & $0.558^{\mathrm{b}}$ \\
\hline $\begin{array}{l}\text { Control group } \\
(n=305)\end{array}$ & $\begin{array}{l}9.28^{c} \\
(5.17-12.4)\end{array}$ & $\begin{array}{l}8.21^{c} \\
(4.12-10.94)\end{array}$ & $\begin{array}{l}6.83^{c} \\
(2.8-9.23)\end{array}$ & $<0.0001^{\mathrm{b}}$ \\
\hline p-value & $<0.001^{\mathrm{a}}$ & $<0.012^{\mathrm{a}}$ & $<0.001^{\mathrm{a}}$ & \\
\hline
\end{tabular}

Abbreviations: FGR, fetal growth restriction; Hcy, homocysteine.

${ }^{a}$ Mann-Whitney U-test

${ }^{\mathrm{b}}$ Friedman test

${ }^{c_{p}}<0.0001$ post-hoc Tukey test (10-14 weeks versus $20-24$ weeks versus $30-34$ weeks) 

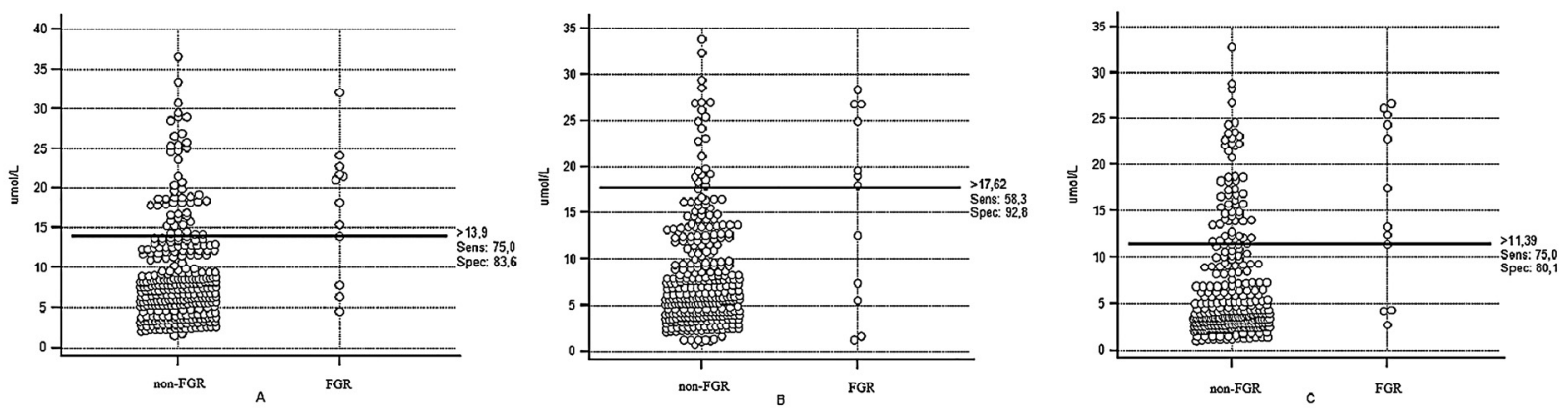

Fig. 1 Graphical characteristics of optimal cut-off levels of homocysteine concentrations in the first (A), second (B), and third (C) trimesters of pregnancy.

abnormal stability, compared with decreasing concentrations of Hcy during gestation in the control group ( - Table 3 ).

The results of the analysis of the ROC determined optimal cut-off levels of Hcy concentrations $13.9 \mathrm{umol} / \mathrm{L}$ at between 10 and 14 weeks, 17.62 umol/L at between 20 and 24 weeks, and $11.39 \mathrm{umol} / \mathrm{L}$ at between 30 and 34 weeks (- Fig. 1). There were no significant differences between the AUC depending on the period of gestation (-Fig. 2). However, the highest DOR value (17.9) was in Hcy determined at between 20 and 24 weeks of gestation, but with a low sensitivity of $58.3 \%$, compared with Hcy determined at between 10 and 14 weeks, with a DOR of 15.6 with sensitivity of $75 \%$ and specificity of $83.6 \%$ (-Table 4 ).

\section{Discussion}

Results of our cohort study showed that, despite the clinical homogeneity of the groups, $3.8 \%$ of the observed patients, without any risk factors, were complicated by FGR. Newborns with FGR had a lower Apgar score and were more often transferred to the intensive care unit, as confirmed by the study by Melchiorre et al., ${ }^{2}$ but did not present a higher frequency of stillbirth, malformations, and neonatal mortality.

In our study, the concentrations of serum Hcy in women with FGR were $19.65 \mathrm{umol} / \mathrm{L}$ at between 10 and 14 weeks, $18.49 \mathrm{umol} / \mathrm{L}$ at between 20 and 24 weeks, and 15.36 umol/L at between 30 and 34 weeks and were significantly different from those of women with normal fetal growth. These results are similar to those of studies by Bergen et al., ${ }^{32}$ Vollset et al., ${ }^{33}$ who also found significantly higher Hcy concentrations at the $1^{\text {st }}$ trimester of pregnancy in women with FGR, and by Furness et al., ${ }^{34}$ who investigated high Hcy concentrations at the $2^{\text {nd }}$ trimester of pregnancy in women with FGR. Yeter et al., ${ }^{14}$ Gadhok et al., ${ }^{35}$ and Jiang et al. ${ }^{17}$ determined increased Hcy levels in the $3^{\text {rd }}$ trimester of pregnancy in women with FGR. However, several

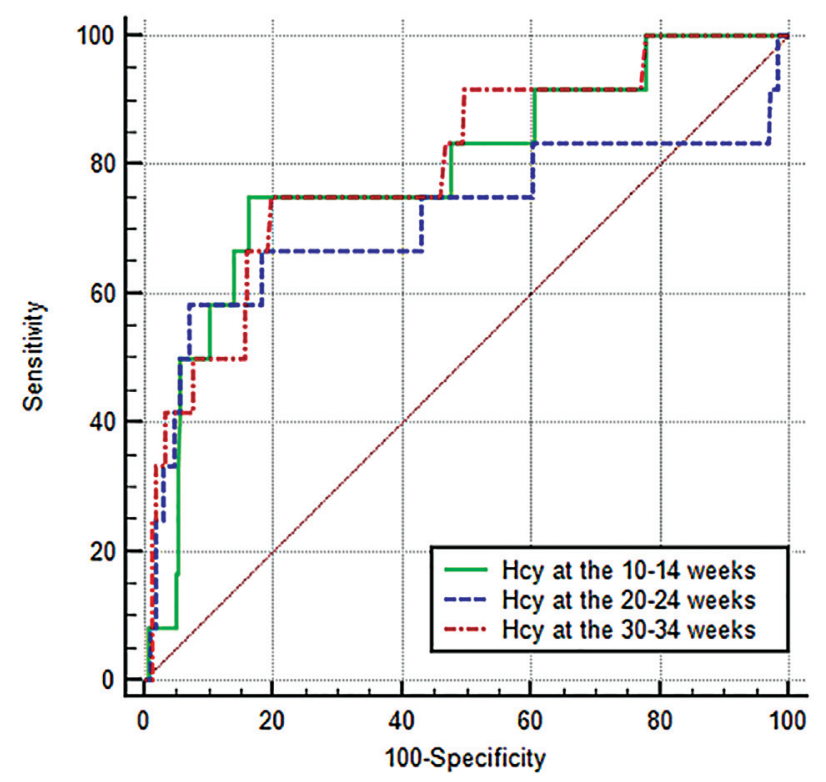

Fig. 2 Illustration of comparison of ROC curves for homocysteine (Hcy) concentrations depending on period of gestation.

Table 4 Results of ROC-analysis of homocysteine in different weeks of gestation

\begin{tabular}{|c|c|c|c|c|c|c|c|c|}
\hline Gestational period of Hcy evaluation & AUC & Se (\%) & Sp (\%) & $p$-value & $\mathrm{J}$ - index & $+\mathrm{LR}(95 \mathrm{Cl})$ & $-\mathrm{LR}(95 \mathrm{Cl})$ & DOR \\
\hline 10-14 weeks & $0.788^{\mathrm{a}}$ & 75 & 83.6 & $<0.001$ & 0.586 & $\begin{array}{l}4.58 \\
(3.0-6.9)\end{array}$ & $\begin{array}{l}0.3 \\
(0.1-0.8)\end{array}$ & $\overline{15.2}$ \\
\hline 20-24 weeks & $0.712^{\mathrm{a}}$ & 58.3 & 92.8 & 0.049 & 0.511 & $\begin{array}{l}8.09 \\
(4.3-15.1)\end{array}$ & $\begin{array}{l}0.45 \\
(0.2-0.9)\end{array}$ & 17.9 \\
\hline 30-34 weeks & $0.799^{\mathrm{a}}$ & 75 & 80.1 & $<0.001$ & 0.551 & $\begin{array}{l}3.77 \\
(2.5-5.6)\end{array}$ & $\begin{array}{l}0.31 \\
(0.1-0.8)\end{array}$ & 12.1 \\
\hline
\end{tabular}

AUC, area under the curve; $\mathrm{Cl}$, confidence interval; DOR, diagnostics odds ratio; Hcy, homocysteine; J, Youden's index; -LR, negative likelihood ratio; $+\mathrm{LR}$, positive likelihood ratio; Se, sensitivity; Sp, specificity.

${ }^{a} p>0.05$ pairwise comparison of ROC curves. 
previous studies by D'Anna et al., ${ }^{36}$ Hogg et al., ${ }^{37}$ Cawley et al., ${ }^{38}$ and Gomes et al. ${ }^{39}$ demonstrated the absence of any difference in serum Hcy levels during pregnancy among women who later developed FGR and those who remained with normal fetal growth.

We also noticed high concentrations of Hcy during pregnancy in the patients who developed FGR, in contrast with pregnancies with normal fetal growth, in which Hcy significantly decreased during pregnancy.

The prognostic and diagnostic role of Hcy for FGR was confirmed by analysis of the ROC, which showed good effectiveness at the $1^{\text {st }}$ and $3^{\text {rd }}$ trimesters of pregnancy.

Murphy et al. ${ }^{40}$ observed that mothers with a Hcy concentration $>8.44 \mathrm{umol} / \mathrm{L}$ at 8 weeks of gestation were 3 times more likely to give birth to an infant in the lowest birthweight tertile. In a study by Bergen et al., ${ }^{32}$ pregnancy was complicated by FGR at a Hcy concentration $>8.3$ umol/L (OR: 1.68 [1.16-2.43]) determined at a gestational age of $<18$ weeks. In another study, by Chaudhry et al., ${ }^{41}$ Hcy concentrations $>5.0 \mathrm{umol} / \mathrm{L}$ were significant for the development of FGR (OR: 1.69 [1.227-2.161]) at 8 weeks of gestational age. The data from previous studies differ significantly from those of our study, in which a significant Hcy concentration in the $1^{\text {st }}$ trimester of pregnancy was determined at $13.9 \mathrm{umol} / \mathrm{L}$, and are similar to those of the study by Steegers et al., ${ }^{42}$ which indicates that a Hcy concentration $>15 \mathrm{umol} / \mathrm{L}$ is significant for the development of FGR.

The role of Hcy assessment in the $2^{\text {nd }}$ trimester of pregnancy remains unclear. Maged et al. ${ }^{16}$ also suggested a certain role of serum Hcy determination as a prognostic and diagnostic marker for FGR, but in combination with Doppler velocimetry of the uterine artery.

As for the $3^{\text {rd }}$ trimester of pregnancy, there were enough case-control studies at the time of the clinical manifestation of FGR, ${ }^{17,42-45}$ but this does not make it possible to predict HFR, since it had already developed.

We have also identified some limitations of the present study. For example, the present study investigated patients with low risk of FGR because the well-known FGR risk factors were added to the exclusion criteria. One of the limitations of the study may also be a relatively small sample size of patients with FGR, but this is a common issue for prospective studies as judged by other publications.

\section{Conclusion}

The results of our study showed that the assessment of serum Hcy concentration at the $1^{\text {st }}$ trimesters of pregnancy may be used as a predictor of FGR. Also, we hypothesize that assessment of serum Hcy concentrations in the $2^{\text {nd }}$ and $3^{\text {rd }}$ trimesters of pregnancy can be an additional marker of FGR.

\section{Contributions}

All authors had full access to all of the data in the present study and take responsibility for the integrity of the data and the accuracy of the data analysis. Study concept and design: Akylbek Tussupkaliyev, Andrey Gaiday, Lazzat Balash. Acquisition of data: Akylbek Tussupkaliyev, Andrey Gaiday. Statistical analyses and data interpretation: Akylbek Tussupkaliyev, Andrey Gaiday, Lazzat Balash. Drafting of the manuscript: Andrey Gaiday, Lazzat Balash. Obtained funding: Akylbek Tussupkaliyev. Study supervision: Akylbek Tussupkaliyev.

\section{Conflicts of Interests}

The authors have no conflict of interests to declare.

\section{Acknowledgments}

The authors are grateful to West Kazakhstan Marat Ospanov Medical University for funding and assisting in the conduction of the study. Also, the authors are grateful to Sagira Zhumugulova for consultations and implementation of the laboratory part of the study, and to Saule Bermagambetova for providing scientific support for the study.

\section{References}

1 Nardozza LM, Caetano AC, Zamarian AC, Mazzola JB, Silva CP, Marçal VMG, et al. Fetal growth restriction: current knowledge. Arch Gynecol Obstet. 2017;295(05):1061-1077. Doi: 10.1007/ s00404-017-4341-9

2 Melchiorre K, Sharma R, Khalil A, Thilaganathan B. Maternal cardiovascular function in normal pregnancy: evidence of maladaptation to chronic volume overload. Hypertension. 2016;67(04):754-762. Doi: 10.1161/HYPERTENSIONAHA.115.06667

3 Maršál K. Physiological adaptation of the growth-restricted fetus. Best Pract Res Clin Obstet Gynaecol. 2018;49:37-52. Doi: 10.1016/j.bpobgyn.2018.02.006

4 Wang Y, Gu Y, Granger DN, Roberts JM, Alexander JS. Endothelial junctional protein redistribution and increased monolayer permeability in human umbilical vein endothelial cells isolated during preeclampsia. Am J Obstet Gynecol. 2002;186(02): 214-220. Doi: 10.1067/mob.2002.119638

5 Triunfo S, Lobmaier S, Parra-Saavedra M, Crovetto F, Peguero A, Nadal A, et al. Angiogenic factors at diagnosis of late-onset smallfor-gestational age and histological placental underperfusion. Placenta. 2014;35(06):398-403. Doi: 10.1016/j.placenta.2014.03.021

6 Hughes AE, Sovio U, Gaccioli F, Cook E, Charnock-Jones DS, Smith GCS. The association between first trimester AFP to PAPP-A ratio and placentally-related adverse pregnancy outcome. Placenta. 2019;81:25-31. Doi: 10.1016/j.placenta.2019.04.005

7 Boeldt DS, Bird IM. Vascular adaptation in pregnancy and endothelial dysfunction in preeclampsia. J Endocrinol. 2017;232(01): R27-R44. Doi: 10.1530/JOE-16-0340

8 Ji L, Brkić J, Liu M, Fu G, Peng C, Wang YL. Placental trophoblast cell differentiation: physiological regulation and pathological relevance to preeclampsia. Mol Aspects Med. 2013;34(05):981-1023. Doi: 10.1016/j.mam.2012.12.008

9 Sherrell H, Dunn L, Clifton V, Kumar S. Systematic review of maternal Placental Growth Factor levels in late pregnancy as a predictor of adverse intrapartum and perinatal outcomes. Eur J Obstet Gynecol Reprod Biol. 2018;225:26-34. Doi: 10.1016/j. ejogrb.2018.03.059

10 Herraiz I, Simón E, Gómez-Arriaga PI, Quezada MS, GarcíaBurguillo A, López-Jimenez EA, et al. Clinical implementation of the sFlt-1/PIGF ratio to identify preeclampsia and fetal growth restriction: A prospective cohort study. 
Pregnancy Hypertens. 2018;13:279-285. Doi: 10.1016/j.preghy.2018.06.017

11 Bækgaard Thorsen LH, Bjørkholt Andersen L, Birukov A, Lykkedegn S, Dechend R, Jørgensen JS, Christesen HK, et al. Prediction of birth weight small for gestational age with and without preeclampsia by angiogenic markers: an Odense Child Cohort study.J Matern Fetal Neonatal Med. 2020;33(08):1377-1384. Doi: 10.1080/14767058.2018.1519536

12 Tussupkaliyev A, Gaiday A, Bermagambetova S, Aniuliene R. [Hypertension of Pregnancy Associated with Hypergomocysteinemia of the First Trimester of Pregnancy]. Georgian Med News. 2018;(276):40-46

13 Tussupkaliyev A, Gaiday A, Bermagambetova S, Arenova S, Kaldigulova L, Dinets A. Urinary placental growth factor determined in the first trimester of pregnancy as a predictor of preeclampsia. Pregnancy Hypertens. 2020;21:63-67. Doi: 10.1016/j.preghy.2020.05.003

14 Yeter A, Topcu HO, Guzel AI, Ozgu E, Danisman N. Maternal plasma homocysteine levels in intrauterine growth retardation. J Matern Fetal Neonatal Med. 2015;28(06):709-712. Doi: 10.3109/14767058.2014.929110

15 Gaiday AN, Tussupkaliyev AB, Bermagambetova SK, Zhumagulova SS, Sarsembayeva LK, Dossimbetova MB, et al. Effect of homocysteine on pregnancy: A systematic review. Chem Biol Interact. 2018;293:70-76. Doi: 10.1016/j.cbi.2018.07.021

16 Maged AM, Saad H, Meshaal H, Salah E, Abdelaziz S, Omram E, et al. Maternal serum homocysteine and uterine artery Doppler as predictors of preeclampsia and poor placentation. Arch Gynecol Obstet. 2017;296(03):475-482. Doi: 10.1007/s00404017-4457-y

17 Jiang HL, Cao LQ, Chen HY. Blood folic acid, vitamin B12, and homocysteine levels in pregnant women with fetal growth restriction. Genet Mol Res. 2016;15(04):1-8. Doi: 10.4238/ gmr15048890

18 Pandey K, Dubay P, Bhagoliwal A, Gupta N, Tyagi G. Hyperhomocysteinemia as a risk factor for IUGR. J Obstet Gynaecol India. 2012;62(04):406-408. Doi: 10.1007/s13224-012-0287-9

19 Dymara-Konopka W, Laskowska M. The role of nitric oxide, ADMA, and homocysteine in the etiopathogenesis of preeclampsia-review. Int J Mol Sci. 2019;20(11):2757. Doi: 10.3390/ ijms20112757

20 Audette MC, Kingdom JC. Screening for fetal growth restriction and placental insufficiency. Semin Fetal Neonatal Med. 2018;23 (02):119-125. Doi: 10.1016/j.siny.2017.11.004

21 Vayssière C, Sentilhes L, Ego A, Bernard C, Camborieu D, Flamant $C$, et al. Fetal growth restriction and intra-uterine growth restriction: guidelines for clinical practice from the French College of Gynaecologists and Obstetricians. Eur J Obstet Gynecol Reprod Biol. 2015;193:10-18. Doi: 10.1016/j. ejogrb.2015.06.021

22 O'Gorman N, Salomon LJ. Fetal biometry to assess the size and growth of the fetus. Best Pract Res Clin Obstet Gynaecol. 2018; 49:3-15. Doi: 10.1016/j.bpobgyn.2018.02.005

23 Hiersch L, Melamed N. Fetal growth velocity and body proportion in the assessment of growth. Am J Obstet Gynecol. 2018;218(2S): S700-711.e1. Doi: 10.1016/j.ajog.2017.12.014

24 Walker KF, Thornton JG. Delivery at term: when, how, and why. Clin Perinatol. 2018;45(02):199-211. Doi: 10.1016/j.clp.2018.01.004

25 Committee Opinion No 700: Methods for Estimating the Due Date. Obstet Gynecol. 2017 May;129(05):e150-e154https:// journals.lww.com/greenjournal/Fulltext/2017/05000/Committee_ Opinion_No_700_Methods_for_Estimating.50.aspx

26 Pillay P, Janaki S, Manjila C. A comparative study of gravidogram and ultrasound in detection of IUGR. J Obstet Gynaecol India. 2012;62(04):409-412. Doi: 10.1007/s13224-012-0292-z

27 Nicolaides KH, Wright D, Syngelaki A, Wright A, Akolekar R. Fetal Medicine Foundation fetal and neonatal population weight charts. Ultrasound Obstet Gynecol. 2018;52(01):44-51. Doi: 10.1002/uog.19073

28 WHO Multicentre Growth Reference Study Group. WHO Child Growth Standards based on length/height, weight and age. Acta Paediatr Suppl. 2006;450:76-85. Doi: 10.1111/j.1651-2227.2006. tb02378.x

29 Sundrehagen E, Axis Biochemicals ASinventors. Enzymatic assay for homocysteine and a kit therefor. European Patent EP 623174/ US5631127. 1990

30 Glas AS, Lijmer JG, Prins MH, Bonsel GJ, Bossuyt PM. The diagnostic odds ratio: a single indicator of test performance. J Clin Epidemiol. 2003;56(11):1129-1135. Doi: 10.1016/s0895-4356 (03)00177-X

31 DeLong ER, DeLong DM, Clarke-Pearson DL. Comparing the areas under two or more correlated receiver operating characteristic curves: a nonparametric approach. Biometrics. 1988;44(03): 837-845

32 Bergen NE, Schalekamp-Timmermans S, Jaddoe VW, Hofman A, Lindemans J, Russhcher $\mathrm{H}$, et al. Maternal and neonatal markers of the homocysteine pathway and fetal growth: The Generation $\mathrm{R}$ Study. Paediatr Perinat Epidemiol. 2016;30(04):386-396. Doi: 10.1111/ppe.12297

33 Vollset SE, Refsum H, Irgens LM, Emblem BM, Tverdal A, Gjessing HK, et al. Plasma total homocysteine, pregnancy complications, and adverse pregnancy outcomes: the Hordaland Homocysteine study. Am J Clin Nutr. 2000;71(04):962-968. Doi: 10.1093/ajcn/ 71.4.962

34 Furness D, Fenech M, Dekker G, Khong TY, Roberts C, Hague W. Folate, vitamin B12, vitamin B6 and homocysteine: impact on pregnancy outcome. Matern Child Nutr. 2013;9(02):155-166. Doi: $10.1111 / \mathrm{j} .1740-8709.2011 .00364 . x$

35 Gadhok AK, Sinha M, Khunteta R, Vardey SK, Upadhyaya C, Sharma TK, et al. Serum homocysteine level and its association with folic acid and vitamin B12 in the third trimester of pregnancies complicated with intrauterine growth restriction. Clin Lab. 2011;57(11-12):933-938

36 D'Anna R, Baviera G, Corrado F, Ientile R, Granese D, Stella NC. Plasma homocysteine in early and late pregnancies complicated with preeclampsia and isolated intrauterine growth restriction. Acta Obstet Gynecol Scand. 2004;83(02):155-158. Doi: 10.1111/ j.0001-6349.2004.00291.x

37 Hogg BB, Tamura T, Johnston KE, Dubard MB, Goldenberg RL. Second-trimester plasma homocysteine levels and pregnancyinduced hypertension, preeclampsia, and intrauterine growth restriction. Am J Obstet Gynecol. 2000;183(04):805-809. Doi: 10.1067/mob.2000.109044

38 Cawley S, O'Malley EG, Kennedy RAK, Reynolds CME, Molloy AM, Turner MJ. The relationship between maternal plasma homocysteine in early pregnancy and birth weight. J Matern Fetal Neonatal Med. 2020;33(18):3045-3049. Doi: 10.1080/14767058.2019.1567705

39 Gomes TS, Lindner U, Tennekoon KH, Karandagoda W, Gortner L, Obeid R. Homocysteine in small-for-gestational age and appropriate-for-gestational age preterm neonates from mothers receiving folic acid supplementation. Clin Chem Lab Med. 2010;48(08): 1157-1161. Doi: 10.1515/CCLM.2010.235

40 Murphy MM, Scott JM, Arija V, Molloy AM, Fernandez-Ballart JD. Maternal homocysteine before conception and throughout pregnancy predicts fetal homocysteine and birth weight. Clin Chem. 2004;50(08):1406-1412. Doi: 10.1373/clinchem.2004.032904

41 Chaudhry SH, Taljaard M, MacFarlane AJ, Gaudet LM, Smith $\mathrm{GN}$, Rodger $\mathrm{M}$, et al. The role of maternal homocysteine concentration in placenta-mediated complications: findings from the Ottawa and Kingston birth cohort. BMC Pregnancy Childbirth. 2019;19(01):75. Doi: 10.1186/ s12884-019-2219-5 
42 Steegers-Theunissen RP, Van Iersel CA, Peer PG, Nelen WL, Steegers EA. Hyperhomocysteinemia, pregnancy complications, and the timing of investigation. Obstet Gynecol. 2004;104(02): 336-343. Doi: 10.1097/01.AOG.0000129955.47943.2a

43 Pagán K, Hou J, Goldenberg RL, Cliver SP, Tamura T. Mid-pregnancy serum homocysteine and B-vitamin concentrations and fetal growth. Nutr Res. 2002;22(10):1133-1141
44 Ronnenberg AG, Goldman MB, Chen D, Aitken IW, Willet W, Selhub J, et al. Preconception homocysteine and B vitamin status and birth outcomes in Chinese women. Am J Clin Nutr. 2002;76 (06):1385-1391. Doi: 10.1093/ajcn/76.6.1385

45 Infante-Rivard C, Rivard GE, Gauthier R, Théorêt Y. Unexpected relationship between plasma homocysteine and intrauterine growth restriction. Clin Chem. 2003;49(09):1476-1482. Doi: 10.1373/49.9.1476 